\title{
ASSESSMENT AND ANALYSIS OF THE DECISION OF THE Alberta COURT OF APPEAL IN OMERS ENERGY V. ALBERTA (ENERGY RESOURCES CONSERVATION BOARD)
}

\author{
ALICIA QuESNEL ${ }^{*}$ AND AARON ROGERS ${ }^{* *}$
}

This article provides an assessment of how the findings of the Alberta Court of Appeal in OMERS Energy v. Alberta (Energy Resources Conservation Board) compare and conflict with the approach historically taken by Canadian courts addressing the capability of a well and related issues. The authors then provide an analysis of uncertainties created by the findings of the Court and discuss the implications of the decision for the upstream oil and gas industry.
Cet article donne une évaluation de la manière dont les conclusions de la Cour d'appel de l'Alberta dans OMERS Energy c. Alberta (Energy Resources Conservation Board) se comparent et s'opposent aux approches traditionnellement prises par les tribunaux canadiens abordant la capacité d'un puits et des questions connexes. L'auteur donne ensuite une analyse des incertitudes créées par les conclusions de la Cour et discute des implications de la décision pour le secteur gazier et pétrolier en amont.

\section{TABLE OF CONTENTS}

I. INTRODUCTION . . . . . . . . . . . . . . . . . . . . . . . . . . 337

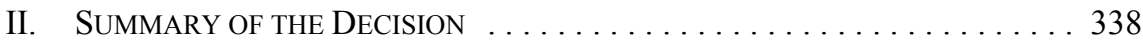

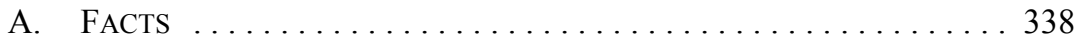

B. The Energy Resources Conservation BoArd Decision . . . 340

C. The Court of APPEAL Decision . . . . . . . . . . . . . . . . . 342

III. ASSESSMENT OF THE DECISION . . . . . . . . . . . . . . . . . 343

A. Reliance on United States Case LaW . . . . . . . . . . . . . . 343

B. LACK OF ANALYSIS OF CANADIAN CASE LAW . . . . . . . . . . . . . 349

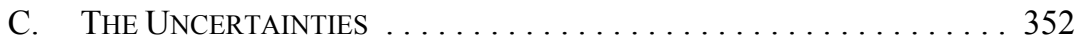

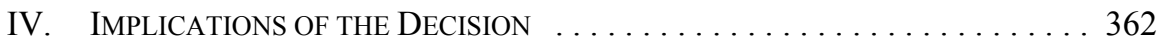

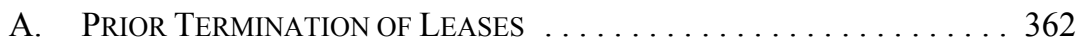

B. TOP LEASING . . . . . . . . . . . . . . . . . . . . . . 364

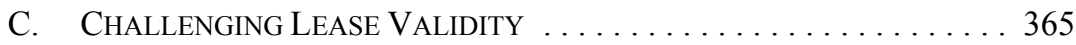

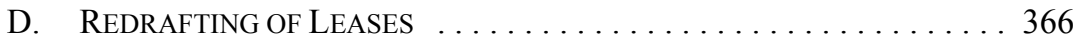

E. INDUSTRY RESPONSE AND BEST PRACTICES . . . . . . . . . . . . . 367

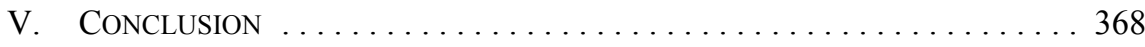

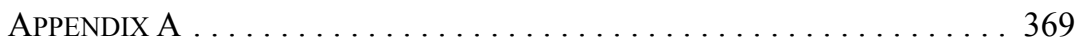

\section{INTRODUCTION}

On 7 September 2011, the Alberta Court of Appeal released its decision in OMERS Energy v. Alberta (Energy Resources Conservation Board), ${ }^{1}$ a long awaited appeal of

* $\quad$ Partner at Burnet, Duckworth \& Palmer LLP.

Legal Counsel at Inter Pipeline Fund. The authors gratefully acknowledge the assistance of Ashley Weldon, Associate, and Brittney LaBranche, Articling Student, of Burnet, Duckworth \& Palmer LLP. 2011 ABCA 251, 513 AR 292 [OMERS], aff'g Energy Resources Conservation Board, OMERS Energy Inc, Section 39 Review of Well Licences No 0336235 and No 0392996, Warwick Field (12 May 2009), ERCB Decision 2009-037 [OMERS (ERCB)]. 
Decision 2009-037 ${ }^{2}$ of the Energy Resources Conservation Board (ERCB) on the meaning of a well "capable of producing the leased substances" for the purposes of determining a lessee's right to take advantage of the shut-in well provisions of a freehold lease. In its decision, the ERCB determined that "'capable of producing the leased substances' is to be interpreted to mean the demonstrated, present ability of a well on the lands to produce the leased substances in a meaningful quantity within the timeframes contemplated in the lease."

The Court of Appeal's confirmation of this surprising and somewhat controversial ERCB decision is an important one that will have significant immediate and long-term implications for the upstream oil and gas industry.

Surprisingly, until OMERS, Canadian courts had not definitively determined what it meant for a well to be "capable of producing the leased substances." Yet this simple phrase has been commonly used in a variety of freehold lease forms in Canada, including all of the current Canadian Association of Petroleum Landmen (CAPL) lease forms. It is typically used either in the Habendum clause to define the duration of the estate granted by a lessor to a lessee upon the issuance of the lease or in the shut-in or suspended well clause to limit the duration of that estate. ${ }^{4}$ What $O M E R S$ has confirmed is that this phrase, when used, is a vitally important part of the freehold lease.

In the first part of this article, we examine these decisions with our observation that they appear to introduce into Canadian oil and gas law the conceptual underpinnings of the implied covenants of reasonable development and marketing that exist under United States law without adequately defining either the nature or scope of these obligations. As a result, the OMERS decision has introduced significantly more uncertainty into a regime that previously operated on a somewhat more predictable basis. Specifically, the ERCB and the Alberta Court of Appeal have introduced, but have not adequately determined, a number of important issues that will be left for future courts to address.

In the second part of this article we examine the uncertainties created by the findings of the Court, the broader implications of the decision to the industry, and the general state of the industry's response to the decision.

\section{SUMmary OF THE DeCiSION}

\section{A. FACTS}

The material facts of the case are straightforward and not in dispute. Dennis Cymbaluk was the freehold owner of the mines and minerals underlying the northwest quarter of section

OMERS (ERCB), ibid.

Ibid at 9 .

In Berkheiser v Berkheiser, [1957] SCR 387, the Supreme Court of Canada characterized the oil and gas lease as a "profit à prendre" (ibid at 392). On this characterization, the "estate" that is granted by the freehold lease is not a "lease" in the classical sense. Rather, it is a right in relation to land (which, at common law, is treated as an interest in land and referred to as an incorporeal hereditament that the lessor grants to the lessee to go onto the lands and capture the minerals, which become possessory upon capture, entitling the lessee to remove the minerals from the lands. The "duration" of the estate granted is the period that the right to enter upon the lands and capture the minerals continues to exist. 
4-54-14-W4M (the Lands). On 8 February 2001, Cymbaluk granted a CAPL 91 form of petroleum and natural gas lease in respect of the Lands (the Lease) to Heritage Freehold Specialists \& Co. for a primary term of five years. The Lease was protected by a caveat registered against title to the Lands. OMERS Energy Inc. (OMERS) was the successor to the interest of the lessee under the Lease. ${ }^{5}$

Under a separate lease relating to the southwest quarter of 4-54-14-W4M, OMERS obtained a well licence and drilled the 100/5-4-54-14-W4M/00 gas well (the 5-4 well), which was spud on 14 August 2005 and put on production in December 2005. ${ }^{6}$ On 26 January 2006, OMERS wrote to Cymbaluk to advise him that the Lease was continuing on the basis of pooled production from the 5-4 well, as provided for in the Lease. ${ }^{7}$

Shortly thereafter, the 5-4 well encountered water loading difficulties and was shut-in on 28 March 2006. An unsuccessful water clean-out operation was conducted on 9 May 2006 after production testing resulted in gas depletion in 13 minutes. The 5-4 well remained shutin until 9 November 2006, at which time a second unsuccessful water clean-out and bridgeplugging operation was conducted and production testing resulted in gas depletion in three minutes. The 5-4 well remained shut-in until 25 January 2008, on which date it was production tested and produced gas for 199 hours at an average rate of $1.1103 \mathrm{~m} 3 / \mathrm{d}$ from 25 January 2008 to 30 January $2008 .^{8}$

On 20 June 2007, Eva Cymbaluk, successor in title to Dennis Cymbaluk, granted a petroleum and natural gas lease in respect of the Lands to Cavalier Land Ltd. for a primary term of three years. Montane Resources Ltd. (Montane) is the successor to the interest of the lessee under that lease. ${ }^{9}$

Montane served OMERS with a Notice to Take Proceedings on its caveat under section 138(1) of the Land Titles Act. ${ }^{10}$ In response, OMERS commenced proceedings at the Alberta Court of Queen's Bench on 31 January 2008, seeking a declaration that its leasehold interest protected by its caveat was valid. ${ }^{11}$

Prior to the hearing of the action commenced by OMERS at the Court of Queen's Bench, OMERS applied for and obtained well licences to drill a new well on the pooled lands and to recomplete the 5-4 well in a new formation (the Well Licences). In February 2008, OMERS recompleted the 5-4 well in the McLaren formation and put it on production. At the same time, OMERS drilled the 102/5-4-54-14-W4M/00 gas well into the Colony formation and also put it on production. ${ }^{12}$

OMERS, supra note 1 at para 4.

Ibid at para 5 .

Ibid at para 6 .

Ibid at para 7.

Ibid at para 8 .

RSA 2000, c L-4.

OMERS, supra note 1 at para 9.

Ibid at paras 10-11. 
On 20 June 2008, after becoming aware of the Well Licences, Montane applied to the ERCB under section 39 of the Energy Resources Conservation Act ${ }^{13}$ to review the Well Licences on the basis that OMERS did not have a valid and subsisting lease for the Lands entitling it to produce from the spacing unit. ${ }^{14}$ The ERCB suspended both Well Licences on 14 August 2008 pending a hearing to determine OMERS' entitlement to hold the Well Licences. $^{15}$

\section{B. THE ENERGy RESOURCES CONSERVATION BOARD DECISION}

The ERCB hearing was held from 10-12 February 2009. In the ERCB's view, OMERS' entitlement to hold a well licence depended on the validity of the Lease. Determining the validity of the Lease required the ERCB to interpret the meaning of the phrase "capable of producing the leased substances" as used in the suspended well clause of the Lease. ${ }^{16}$ The relevant portions of the CAPL 91 form of lease considered by the ERCB are set out in Appendix A.

In reaching its interpretation of the phrase "capable of producing the leased substances," the ERCB considered both the physical state of the well and the quantity of leased substances that the well was capable of producing. ${ }^{17}$

Relying on the Canadian Oxford Dictionary, the ERCB concluded that "capable" meant "a present or existing ability or fitness of a thing to perform its purpose in the manner intended." 18 In order to be considered to be capable, a well must be able to be "turned on" and must immediately produce without further operations being conducted to enable such production. $^{19}$

Next, the ERCB addressed the quantity of production that would be required to satisfy the requirement of "capable of producing the leased substances." The ERCB disagreed with the submission of OMERS that no minimum volumetric quantity of production should be implied because the parties to the Lease had not chosen to specify any such requirement in the suspended wells clause. Interpreting the Lease through the lens of mutual benefit to the lessor and lessee, the ERCB noted that the suspended well payment was a nominal payment only and that the lessor would have anticipated receiving royalty payments under the Lease from a producing well. ${ }^{20}$ The parties would not have intended that the Lease could be continued for an extended period beyond the primary term by a well that could produce only a miniscule or insignificant amount of leased substances, as such an interpretation would allow a lease to continue almost indefinitely with no real benefit to the lessor. ${ }^{21}$ This was found to be contrary to both the intentions of the parties as expressed in the Lease and

RSA 2000, c E-10.

OMERS, supra note 1 at para 12 .

Ibid.

OMERS (ERCB), supra note 1 at 6.

Ibid at 7 .

Ibid, citing the Canadian Oxford Dictionary, $2 \mathrm{~d}$ ed, sub verbo "capable."

OMERS (ERCB), ibid.

Ibid at 9 .

Ibid. 
industry practice, ${ }^{22}$ as it would "provide little or no incentive for a lessee to undertake operations to enhance the recovery of leased substances." 23

However, the ERCB did not agree with the submission of Montane that commercial production or production in paying quantities was required to satisfy the requirement that a suspended well be "capable of producing the leased substances." It noted that neither term was used by the parties in the suspended well clause or was "so well established in the industry or under Canadian law" 24 that it could reasonably be inferred. The ERCB also noted that the offset well clause contained in the Lease used the defined term "commercial production," but that the Habendum did not. As a result, the ERCB concluded that the parties to the Lease had not intended the phrase "capable of producing the leased substances" to require commercial production. ${ }^{25}$

Instead, the ERCB held that the phrase "capable of producing the leased substances" required that the suspended well be capable of "some material, as in a meaningful, volume of production." ${ }^{26}$ Unfortunately, the ERCB chose not to define this standard, emphasizing instead that what is "material" or "meaningful" would depend on the relevant factors of each case. $^{27}$

Finally, the ERCB was cognizant of the fact that a well might not be producing or capable of producing the leased substances at all times. Assessing the Habendum and the suspended wells clause of the Lease together, it held that "the lessee must undertake operations if a producing well is no longer producing the leased substances or if a suspended or shut-in well is no longer capable of producing the leased substances" ${ }^{28}$ within the 90 -day cessation period contained in the Lease. Thus, if any work were required for the well to attain or maintain the ability to produce the leased substances, in particular work falling within the definition of "operations" under the Lease, the lessee would have 90 days to perform such work or else the well would not be capable of producing the leased substances within the meaning of the suspended wells clause. ${ }^{29}$

In summary, the ERCB concluded that the phrase "capable of producing the leased substances" was to be interpreted to mean "the demonstrated, present ability of a well on the lands to produce the leased substances in a meaningful quantity within the timeframes contemplated in the lease." 30

Applying its interpretation to the 5-4 well, the ERCB held that the well could not be considered to be "capable of producing the leased substances" as required by the suspended well clause. The ERCB found that the evidence established that the 5-4 well was unable to produce on a sustained basis and required further operations to address the water loading 
issues. In its view, a well that was in need of such an operation could not be considered to be "capable." ${ }^{31}$ Notably, the ERCB made this finding notwithstanding evidence presented by OMERS that there remained significant gas reserves in both the Colony and McLaren formations underlying the Lands and that the 5-4 well was otherwise mechanically complete as a result of past production.

Once the 5-4 well was no longer capable of producing the leased substances in meaningful quantities, the ERCB found that OMERS was required to commence further operations within the 90-day cessation clause of the Lease. ${ }^{32}$ As OMERS failed to do so following the 9 May 2006 water clean-out operation, the ERCB held that the Lease terminated by its own terms on 10 May $2006 .^{33}$

\section{The Court of APPEAl Decision}

OMERS sought leave to appeal the OMERS (ERCB) decision on three grounds. On 12 May 2009, the Alberta Court of Appeal granted leave to appeal on the sole question of whether the Board erred in its interpretation of the phrase "capable of producing the leased substances." " The Court of Appeal concluded that the ERCB had not erred and affirmed all material aspects of the ERCB decision.

With respect to the physical state of the well, the Court agreed that to be "capable" meant that "a well could produce in its existing state and configuration, without requiring further operations to produce" 35 and, in particular, "operations" of the kind listed in clause $1(\mathrm{~g})$ of the Lease. Significantly, it noted that to hold that a well could be considered to be "capable" while in need of such operations would defeat the purpose of the 90-day cessation period contained in the Habendum. ${ }^{36}$

In assessing the quantity of production that would be required in order for a well to be considered to be "capable of producing the leased substances," the Court of Appeal agreed with the ERCB that a miniscule or insignificant amount of production would not be sufficient and that a meaningful quantity of production was required. It was strongly influenced by American jurisprudence that interpreted the purpose of an oil and gas lease as providing a mutual benefit for both the lessor and the lessee. In the Court's view,

the parties intended that to continue the lease past the primary term, the well must be capable of producing a volumetric quantity that would encourage both production and operations to maximize that production. The lessee is granted a substantial primary term where it has great discretion as to timing of its operations. But if it seeks to hold the lease past the primary term, there are conditions. The various lease provisions were intended to balance the parties' rights by ensuring that the interests of the lessee are protected, while at the same time ensuring that the term of the lease cannot be extended indefinitely when there is no reasonable expectation of a return to profitability in the near future. ${ }^{37}$

Ibid at 13 .

Ibid at 14.

Ibid.

OMERS, supra note 1.

Ibid at para 81 .

Ibid.

Ibid at para 94. 
The view that the Lease should be interpreted in a manner that benefits the lessor as well as the lessee is reflected in numerous other statements by the Court, most notably:

[A]n interpretation suggesting a lessor would agree to tie up its land to a lessee beyond the primary term for speculative purposes only is unreasonable. ${ }^{38}$

And:

That rationale seeks to support the common objective of the parties to benefit by profit from development of the resource. It strains common sense to think a lessor would agree to tie up its land past the primary term, and perhaps indefinitely, for a lessee's speculative purposes only and for a well that lacks commercial viability.... [T] $]$ here must be a meaningful amount of resource capable of production. It was never intended that the shut-in well clause could allow a lessee to hold a property for purely speculative purposes. There must be some commercial viability to the well. ${ }^{39}$

\section{ASSESSMENT OF THE DECISION}

As noted above, we are somewhat perplexed by both the ERCB's decision in OMERS (ERCB), as well as the Alberta Court of Appeal's decision in OMERS. An examination of the decision of the Alberta Court of Appeal in OMERS and previous decisions of the ERCB reveals significant reliance on American case law without due regard or consideration for prior Canadian court decisions. While there is no prior Canadian case law directly on point, both the ERCB and the Alberta Court of Appeal failed to consider and assess the obiter dicta of their colleagues that touched on these matters. The result leaves a number of uncertainties and unanswered questions. In our view, these uncertainties have arisen, in large part, because both the ERCB and the Alberta Court of Appeal applied principles of US case law without considering the foundational theory of law upon which the US cases are based.

\section{A. Reliance ON United States CaSe LAW}

Canadian courts have generally been reluctant to rely on US authorities in the interpretation of Canadian freehold oil and gas lease terms. They typically do not do so unless there is either no Canadian case law on point or the American authorities do not contradict Canadian law. ${ }^{40}$ The reason, noted by the late freehold lease authority John Bishop Ballem, is because there are many points of divergence between Canadian law and American law in their interpretation of freehold leases. As Ballem explains:

The American cases, in addition to suffering from a considerable divergence of results arising from the differing views of individual state courts, introduce other elements such as equitable considerations, relief against forfeiture, intention of the parties, and implied covenants. The Canadian approach, on the other hand, has been to look only to the words of the lease and to exclude any outside influences or considerations. ${ }^{41}$

Ibid at para 92.

Ibid at para 95.

OMERS, supra note 1 at para 56, citing Scurry-Rainbow Oil Ltd v Galloway Estate (1993), 138 AR 321

at para 27 (QB) [Scurry-Rainbow].

John Bishop Ballem, The Oil and Gas Lease in Canada, 4th ed (Toronto: University of Toronto Press, 2008) at 109. 
Both the ERCB's decision in OMERS (ERCB) and the Alberta Court of Appeal's decision in $O M E R S$, by contrast, rely heavily on American case authority to support their determinations. While this may not be readily apparent from the ERCB's decision in OMERS $(E R C B)$, as the ERCB failed to cite any case law in that decision, its positions on the matters in issue were clearly illustrated in the previous Desoto decision, ${ }^{42}$ in which it relied extensively on two US decisions, Hydrocarbon Management. v. Tracker Exploration ${ }^{43}$ and Anadarko Petroleum Corp. v. Thompson, ${ }^{44}$ for the following legal propositions:

In Hydrocarbon Management Inc. v. Tracker Exploration Inc., the Court of Appeals of Texas, Seventh District, determined that the phrase "capable of production in paying quantities" means a well that will produce in paying quantities if the well is turned "on" and it begins flowing without additional equipment or repair. In Anadarko Petroleum Corp. v. Thompson, the Supreme Court of Texas held that the completion of a gas well capable of producing in paying quantities but shut in due to a lack of pipeline facilities did not constitute a well "capable of producing in paying quantities." 45

The Alberta Court of Appeal, while recognizing that any reliance on American law should not contradict concepts adopted by Canadian courts ${ }^{46}$ and that Canadian courts are generally reluctant to apply American case law, ${ }^{47}$ nonetheless cited a number of American authorities in support of its determination, including the following:

- Gypsy Oil Co. v. Marsh, ${ }^{48}$ which held that the purpose of the lessor in entering a lease is to have the leased substances produced and marketed so that royalties may be received, while the purpose of the lessee is to produce the leased substances for a profit;

- Garcia v. King, ${ }^{49}$ which held that one must consider the objective of the lessor and the lessee in entering into the lease when interpreting the language, which is to "secure development of the property for the mutual benefit of the parties," 50 and that production in "paying quantities" is to be determined upon a consideration of all matters that "would influence a reasonable and prudent operator"; 51

- Clifton v. Koontz, ${ }^{52}$ which concurred with the Court in Garcia and held further that if a "well were turned 'on', and the well did not flow, because of mechanical problems or because the well needs rods, tubing, or pumping equipment" not be considered to be a well "capable of producing in paying quantities"; and

Alberta Energy and Utility Board (EUB), Desoto Resources Limited, Section 40 Review of Well Licence No 0365128, Joffre Field (17 June 2008), EUB Decision 2008-047 [Desoto (ERCB)], leave to appeal to CA refused, 2008 ABCA 349, [2008] AJ no 1156 (QL) [Desoto].

861 SW 2d 427 (Tex Ct App 1993) [Hydrocarbon Management].

94 SW 3d 550 (Tex Sup Ct 2002) [Anadarko].

Desoto (ERCB), supra note 42 at 10.

OMERS, supra note 1 at para 56, citing Scurry-Rainbow, supra note 40 at para 27.

Ballem, supra note 41 at 109 , cited by OMERS, ibid at para 56.

248 P 329 (Okla Sup Ct 1926), cited by OMERS, ibid at para 57.

164 SW 2d 509 (Tex Sup Ct 1942) [Garcia].

Ibid at 512-13, cited by OMERS, supra note 1 at para 61.

Clifton v Koontz, 325 SW 2d 684 at para 9 (Tex Sup Ct 1959) [Clifton], cited by OMERS, ibid at para 65 .

Clifton, ibid.

Hydrocarbon Management, supra note 43, cited by OMERS, ibid at para 70. 
- Hydrocarbon Management, which held that a "well had to be able to produce in paying quantities once it was turned on and immediately before it was turned off." 54

What is missing from both the ERCB's and the Court's reliance on these authorities, however, is an acknowledgment of the underlying foundation of these determinations and how that foundation differs from the position historically taken by Canadian courts. Specifically, each of these US cases was decided within an "implied covenants" legal framework. The courts in both Oklahoma and Texas have held that, absent any specific or express language to the contrary, there is a covenant implied in every oil and gas lease that the lessee will explore for, develop, produce, and market the leased substances in the manner of a prudent operator. Much of the US case law interpreting freehold oil and gas leases, including the case law cited by the Alberta Court of Appeal, addresses issues surrounding the scope of this duty and the manner in which it feeds into the implied covenants of exploration, development, and marketing. The following passage from George v. Jones ${ }^{55}$ summarizes the rationale for implying this duty:

\begin{abstract}
Such a covenant arises by necessary implication. It would be unjust, unreasonable, and countervene the nature and spirit of the lease, to allow the lessee to continue to hold his term for a considerable length of time, without making any effort to work the mine. Such a construction of the rights of the parties would enable [the lessee] to prevent the lessor from getting his royalties under the express covenant to pay for the same, and deprive him of all opportunity to work the mine himself, or permit others to do so. The law does not tolerate such practical absurdity, nor will it permit the possibility of such injustice. It is of the essence of the lease, necessarily implied, that the lessee shall work the mine with reasonable diligence, or surrender the lease. $^{56}$
\end{abstract}

What we also see in American case law is an extension of the "implied covenants" framework from that of a duty giving rise to a claim for damages and possibly a termination of the lease in the event that the lessee fails to meet its obligations under the lease, to that of an implied limitation on the duration of the estate granted by the lessor. This approach was expressly recognized by the Court in Hydrocarbon Management, where the implied covenant to develop the leased substances was held to operate as a "special limitation" on the lease as follows:

In the absence of express provisions to the contrary, a lessee in any oil and gas lease assumes a number of implied obligations to the lessor with reference to the operation and development of the leasehold premises.... One such covenant is to develop the premises with reasonable diligence... This covenant exists in all situations where the lease is being preserved other than by the payment of delay rentals.... The implied covenants are the result of courts determining that the commitment of the leased premises to the purpose of oil and gas exploration, development, and production is a special limitation upon the lessee's estate, even though it is not expressly stated as a special limitation in the lease. ${ }^{57}$

Hydrocarbon Management, supra note 43, cited by OMERS, ibid at para 71 .

95 NW 2d 609 (Neb Sup Ct 1959) [George]. For a discussion of cause of action for breach of development covenants, see Patrick H Martin \& Bruce M Kramer, eds, Williams \& Meyers, Oil and Gas Law, abridged 4th ed (San Francisco: LexisNexis Matthew Bender, 2010) at $\S 832$. 
Likewise, in an early case, Hanks v. Magnolia Petroleum Co. ${ }^{58}$ the Texas Commission of Appeals took this approach, holding that the lease in question automatically terminated in accordance with its terms as a result of the inability of the lessee to market the leased substances, noting:

\begin{abstract}
The record is wholly devoid of evidence showing that there were any facilities for marketing the gas or any nearby localities or industries which might have furnished a profitable market therefor. No attempt was made to show what the gas could have been sold for at any probable market, nor was there any evidence tending to show that the well was situated in such proximity to any prospective market which would justify the construction of a pipe line for marketing same.
\end{abstract}

The burden was upon him to prove that there was a reasonable expectation and probability of a market for the gas produced from his well at the time of its completion. ${ }^{59}$

In contrast to US courts, Canadian courts have historically been reluctant to incorporate implied covenants into Canadian freehold oil and gas leases. In Canada-Cities Service Petroleum Corp. v. Kininmonth, ${ }^{60}$ the Supreme Court of Canada expressly rejected an attempt by the appellant to follow US precedent and incorporate an implied term into a lease that would have allowed the lessee to continue to drill a well to completion following the expiry of the primary term, even though there was no production at the expiry of the primary term as required under the Habendum clause. ${ }^{61}$ In Freyberg v. Fletcher Challenge Oil and Gas,${ }^{62}$ the Alberta Court of Appeal was highly critical of the trial Court's attempt to imply a covenant into an oil and gas lease on the basis that doing so was "consistent with the commercial realities of a gas lease," holding that the trial judge "erred in law by finding an implied term in the Lease," particularly as the implied term "circumvents case law" to the contrary. ${ }^{63}$ The Court of Appeal favoured a "strict interpretation" of the lease for a number of policy reasons and "sound legal principles which indicate that such [an implied] term is inappropriate." ${ }^{\prime \prime 4}$ The Court reasoned that the implied term was inconsistent with both the "entire agreements" clause of the lease and the "plain and ordinary meaning" of the terms of the lease, which is the basis upon which the lease should be interpreted unless to do so would result in an absurdity. ${ }^{65}$ It further noted that the covenant in question derived from Oklahoma law as a result of Oklahoma-specific statutory enactments. ${ }^{66}$ The strict approach endorsed by the Court of Appeal in Freyberg is reflected in the subsequent decision by the

\title{
24 SW 2d 5 (Tex Sup Ct 1930).
}

Ibid at 6-7.

[1964] SCR 439.

Ibid at 447. The appellant cited Moncrief v Pasotex Petroleum Co, $280 \mathrm{~F} 2 \mathrm{~d}$ 235, (10th Cir 1960) for the proposition set forth in Simons v McDaniel, 7 P 2d 419 (Okla Sup Ct 1932) that "[t]he right to commence a well during the primary term carries with it, by necessary legal implication, the right to complete the well after expiration of the primary term unless negatived by contract terms or loss by abandonment."

2005 ABCA 46, 363 AR 35 at paras 57-59 [Freyberg], rev'g 2002 ABQB 692, 323 AR 45, leave to appeal to SCC refused, 30874 (10 November 2005).

Freyberg, ibid at paras 45-48.

Ibid at para 55 .

Ibid at para 57

Ibid at paras 57-59. 
same court in Kensington Energy Ltd. v. B\&G Energy Ltd.,${ }^{67}$ in which the Court held that the express terms of the applicable shut-in clause contained no requirements to be met by the lessee in order to achieve deemed production and continue the lease except for the payment of the shut-in royalty payment. ${ }^{68}$

Following the Alberta Court of Appeal's decision in OMERS, one wonders whether or not the Canadian distaste for the "implied covenants" framework for legal interpretation still applies.

In OMERS, the Alberta Court of Appeal outlined that the role of the court in interpreting an oil and gas lease is to "search for the intention of the parties by examining the specific words used with regard to the whole contract and the demonstrated intention of the parties." 69 If we examine the rationale cited by the US courts for implying terms into the lease and the rationale of the ERCB for its interpretation of the meaning of "capable of producing the leased substances" based on the "intention of the parties" (cited with approval by the Court of Appeal), we see striking similarities.

In fact, the Court of Appeal expressly noted the similarities between the ERCB's decision in OMERS (ERCB) and the American authorities, holding:

\begin{abstract}
I note that the reasoning behind the concept of "paying quantities" in the American authorities, and that used by the Board for choosing "material" and "meaningful", are very similar. That rationale seeks to support the common objective of the parties to benefit by profit from development of the resource. It strains common sense to think a lessor would agree to tie up its land past the primary term, and perhaps indefinitely, for a lessee's speculative purposes only and for a well that lacks commercial viability.... By using the term "meaningful" the direction of the Board appears to be much the same as that of the American courts in choosing "paying quantities". Before a lessee can take advantage of the Habendum Clause and the Suspended Wells Clause to extend or maintain the lease beyond the primary term, there must be a meaningful amount of resource capable of production. ${ }^{70}$
\end{abstract}

Although the ERCB rejected the requirement for production in "paying quantities" in favour of a "meaningful quantity" standard, the rationale for implying a volumetric minimum outlined by the Court of Appeal in OMERS is the same as the rationale underlying the implied covenant to develop the property under US law:

[T] he purpose and goal of parties entering into such a lease is to develop the resource for the purpose of making a profit. That purpose provides the rationale for concluding that where production extends the primary term of a lease, the parties would have anticipated production at something more than trivial or miniscule production. Certainly they would not have anticipated that a lessee could hold a lease by shutting in a well that was not capable of producing a meaningful amount. ${ }^{71}$ 
These similarities are not surprising when one considers that, historically, the development of the implied covenants analysis applied in the US was itself derived from an "intention of the parties" analysis. As the 8th circuit Court in Brewster v. Lanyon Zinc Co. ${ }^{72}$ explained:

\begin{abstract}
It is conceded, as indeed it must be, that the lease contains no express stipulation as to what, if anything, should be done in the way of searching for and producing oil or gas after the first five years; but it does not follow from this that it is silent on the subject, or that the matter is left absolutely to the will of the lessee. Whatever is implied in a contract is as effectual as what is expressed. Implication is but another name for intention, and if it arises from the language of the contract when considered in its entirety, and is not gathered from the mere expectations of one or both of the parties, it is controlling.
\end{abstract}

The implication, necessarily arising ... the intention which they obviously reflect - is that if, at the end of the five-year period prescribed for original exploration and development, oil and gas, one or both, had been found to exist in the demised premises in paying quantities, the work of exploration, development, and production should proceed with reasonable diligence for the common benefit of the parties, or the premises be surrendered to the lessor. ${ }^{73}$

This lack of a substantive difference between the direct implication of a term and the incorporation of the same term following an interpretation of the intention of the parties to a contract was noted by Justice Côté in dissent in Paddon Hughes Development Co. Ltd. v. Pancontinental Oil Ltd. ${ }^{74}$

The decision in OMERS, therefore, draws heavily on the "implied covenants" legal framework for analysis. The Court's findings that a well "capable" of producing leased substances must be a well that has "the ability to produce in its existing configuration and state of completion" and that a "well could not be capable of producing the leased substances and at the same time in need of an operation" 75 effectively implies into the Lease a covenant to develop the leased Lands and, possibly, to market production. The Court's holding that a well "capable of production" actually means a well capable of production in "meaningful quantities" is, likewise, an incorporation of these same covenants. In support of this interpretation, the Court held that to allow a lessee to "tie up property indefinitely for a quantity of production that would never pay" or for "speculative purposes only is unreasonable."76 That principle underlies the balance of the Alberta Court of Appeal's decision in OMERS. Interestingly, however, it appears to us to be inconsistent with the facts in OMERS, as it was clear that OMERS was not holding the Lease for speculative purposes. Having drilled additional wells and recompleting the 5-4 well, albeit not within the time limitation provided for in the cessation clause, OMERS had established that the Lands could be produced from the McLaren and Colony formations. see Martin \& Kramer, supra note 55 at $\S 802$.

Brewster, ibid at 809-10 [emphasis added].

1998 ABCA 333, 223 AR 180 at para 82.

OMERS, supra note 1 at para 80.

Ibid at para 92. 
In our view, the ERCB and the Court of Appeal have read terms into the Lease that effectively operate as a "special limitation" on the duration of the estate granted by the lessor under the Lease. The fact that the Court framed its analysis as an interpretation of the Lease consistent with the intention of the parties viewed objectively, rather than as an implied covenant, does not substantively affect the impact of its decision.

\section{B. LaCk of Analysis of Canadian CaSe LaW}

Both the ERCB in Desoto (ERCB) and the Alberta Court of Appeal in OMERS were careful to point out that they turned to American authorities only because of the lack of applicable Canadian authorities on point. None were pleaded by any of the parties. While we appreciate that there is no definitive Canadian case law on point, in our view, there is obiter in a number of Canadian cases that the ERCB and the Alberta Court of Appeal could have considered in the analysis of the meaning of the phrase "capable of producing the leased substances." In these cases, Canadian courts have suggested, in contrast to the decisions of the ERCB and the Alberta Court of Appeal in OMERS (ERCB) and OMERS, that in the absence of any specific express requirement under the lease, a well may be held to be "capable of producing the leased substances" based on drill stem tests undertaken prior to the completion of a well and notwithstanding that the well is not, at the time of completion, equipped or tied into a gathering system. We believe that such decisions illustrate that Canadian courts have historically placed more emphasis on the quality and capability of the reservoir than the technical capability of the well.

In the first such case, Shell Oil Co. v. Gunderson, ${ }^{77}$ the Supreme Court of Canada was asked to determine whether a petroleum and natural gas lease had terminated at the end of its primary term due to lack of production. The leased lands were pooled with other lands to form a spacing unit and a well had been drilled on the pooled lands, which was capped and not connected to a gathering system. Although the Court concluded that the capped well on the pooled lands was not sufficient to continue the lease according to the terms of the pooling clause in the lease, it unanimously held that even though the well was capped, not connected to a gathering system, and had never produced, it was nonetheless "capable of producing natural gas., 78

In Canadian Superior Oil Ltd. v. Paddon-Hughes Development Co. Ltd., ${ }^{79}$ the Alberta Court of Appeal was asked to determine whether a petroleum and natural gas lease had terminated as a result of the late payment of a shut-in royalty. The lease expressly permitted the lessee, having commenced to drill a well prior to the expiry of the primary term, to continue to "drill such well to completion with reasonable diligence and dispatch" oil or gas in paying quantities were found, the lease would continue.

While the Court ultimately concluded that the late payment of the shut-in royalty was fatal to the validity of the lease, the fact that the well never produced gas was not. The well was spud on 10 June 1958, seven days prior to the expiration of the primary term of the lease, and

[1960] SCR 424 [Gunderson].

Ibid at 427.

(1969), 3 DLR (3d) 10 (Alta SC (AD)) [Paddon-Hughes], aff'd [1970] SCR 932.

Paddon-Hughes, ibid at 14. 
drilling proceeded continuously until 29 June. Various drilling and testing operations were conducted until 4 August, when the wellbore was perforated to take production from the Shunda formation. Although the well was not yet completed for production and was still in need of additional equipping, the Alberta Court of Appeal nonetheless held that " $\mathrm{t}] \mathrm{h}$ ere is no dispute that these tests indicated that gas 'in paying quantities' (to use a phrase that appears in the lease) was capable of being produced from this well.",

Notably, this determination was made by the Court prior to the well being completed for production, which the Court concluded had occurred on 6 August when the well was rig released. The shut-in payment was not made until 13 August, terminating the lease for the failure to achieve deemed production as of the completion of drilling.

The approach taken by the Alberta Court of Appeal in Canadian Superior Oil Ltd. $v$. $\mathrm{Cull}^{82}$ with respect to the determination of whether a well spud prior to the primary term, completed after the primary term, and not immediately put on production due to a lack of infrastructure, was that such well was deemed to be a well drilled prior to the expiry of the primary term pursuant to the terms of the lease. Similarly to Paddon-Hughes, the lease in question in Cull permitted the lessee to continue to drill a well that was spud within the primary term to completion. The well was spud on 28 November 1957, approximately a month before the expiry of the primary term of the lease on 30 December 1947, and drilling and preparatory operations continued until 8 January 1948 when the service rig was released, at which time there was not yet any infrastructure in place to store or transport production from the well. Material for the tank battery and separator began arriving on site between 5 and 7 January and was installed by 11 January. The well commenced production on 13 January $1957 .{ }^{83}$

As the facts highlight, there was a period of time between the rig release of the well on 8 January and the date on which production from the well commenced on 13 January. The question for the Court was whether this period of non-production was fatal to the continued validity of the lease. The trial judge concluded that, as there was no production for almost a week after the well was completed, the lease expired at the end of the primary term. ${ }^{84}$ The Court of Appeal disagreed, holding that the work that was completed after the rig release and up to 11 January was part of the drilling of the well. ${ }^{85}$ In its view, a clause permitting drilling over the expiry of the primary term would be rendered inoperative if production had to be taken the very moment the well was "completed" (in other words, rig released) since, in every case, there will be a period of time that is required to connect the well to the gathering system and to turn the valves on. The Court suggested that the proper interpretation was one that took into account the "realities of the situation," holding:

In interpreting these clauses, we must keep in mind the realities of the situation and the purposes which are contemplated by the lease. Among these are:

Ibid at 12 [emphasis added].

(1970), 16 DLR (3d) 709 (Alta SC (AD)) [Cull], aff'd [1972] SCR 89 [Cull (SCC)].

Cull, ibid at 710-11.

Ibid at 712 .

Ibid at 714-15. 
(1) a well when drilled to formation will usually require further work to be done to obtain production, as that word is understood in the industry,

(2) a tank battery to store the oil must be constructed and connected to the well, and

(3) production must be maintained to the extent permitted by its oil quota as set by the Conservation Board.

Considering the effect to be given to para. 2 of the lease, the question is not whether the well was flowing the exact moment that the term of the lease expired (in this case when the well was completed), but whether oil can be taken and marketed so that the lessor and lessee will be entitled to the full benefit of the well's production. $^{86}$

As this was not an established production area, it made sense for the lessee to have waited to construct the tank battery until it had determined that the production could be obtained. In affirming the decision, the Supreme Court of Canada noted that on 7 January the well was "capable of producing oil," even though there was no equipment ready to treat and store the production. ${ }^{87}$

Finally, in Kissinger Petroleums Ltd. v. Keith McLean Oil Properties Ltd., ${ }^{88}$ a 1984 decision of the Alberta Court of Appeal, the Court considered whether the lessee could take advantage of a shut-in payment made under the shut-in provisions of the lease prior to the existence of a completed well. The shut-in clause in the lease in question required only that: (1) there be a "well" on the lands from which leased substances are not produced; and (2) that the lack of production was as a result of a lack of or an intermittent, uneconomic, or unprofitable market, or any cause whatsoever beyond the lessee's reasonable control. ${ }^{89}$ The Habendum clause required production at the end of the primary term; however, the third provison of the lease specified that if at the end of the primary term there was no production, but the lessee was then engaged in drilling or working operations, the lease would remain in full force and effect for so long as such drilling or working operations were prosecuted with no cessation of more than 90 consecutive days, and if such operations result in production, so long thereafter as the leased substances are produced. ${ }^{90}$

The lease was issued on 6 March 1970 for a primary term of ten years. No well was commenced on the lands until 1 March 1980. The drilling was completed on 10 March 1980, four days after the expiry of the primary term. Drill stem tests conducted on 10 March indicated that it was capable of a flow rate of gas that amounted to "commercial production." The well was cased and capped and finally rig released on 21 March 1980. In a letter to the lessor, the lessee advised that it had credited an amount to the lessor's account on 4 March 1980 and that this should be considered to be the shut-in royalty payment. ${ }^{91}$

Ibid at 714 .

Cull (SCC), supra note 82 at 93.

(1984), 33 Alta LR (2d) 1 (CA) [Kissinger].

Ibid at 12 .

Ibid at 11-12.

Ibid at 4-6. 
The appellants argued that the shut-in royalty payment could not be made if there was no existing well on the property at the time, since the shut-in clause, to be applicable, required the existence of a well. The Court, however, disagreed:

I find nothing which decides or suggests that a payment which is made by a lessee in advance of the completion of the well, and in anticipation that the well will be capable of commercial production, is not in compliance with the shut-in royalty clause when upon completion of the well it is designated as a shut-in royalty payment and accepted by the lessor as such. ${ }^{92}$

The Court endorsed the applicability of the shut-in royalty provision, which required the existence of a well on the lands, even though a completed well did not exist at the time the lessee took advantage of the shut-in royalty provision.

While none of the above-noted cases answers the question that was before the Court of Appeal in OMERS, and each is distinguishable on its facts, a review may have been sufficient to temper the Court's enthusiasm for relying on American case law and the implied covenants framework incorporated into them.

\section{The UnCERTAINTIES}

As we note above, the reliance by the Alberta Court of Appeal on American case law and its failure to address prior Canadian precedent led to a decision in OMERS that, in our view, resulted in a number of uncertainties for the oil and gas industry. Our sampling below references uncertainties relative to: (1) the meaning of "meaningful quantities"; (2) how "complete" a well must be in order to be "capable" of producing the leased substances; (3) the role of the prudent operator standard in lease interpretation; and (4) what relief is granted by the operation of a typical force majeure clause?

\section{THE “MEANINGFUL QUANTITIES” STANDARD}

The Court of Appeal's determination that a well must be able to produce a "meaningful quantity" of leased substances in order to be "capable of producing the leased substances" has created a significant amount of uncertainty among lessees.

In upholding the finding of the ERCB that a well needed to be able to produce a "meaningful" quantity of leased substances, the Court viewed the Lease through a lens of mutual benefit for both the lessor and the lessee. It made a number of very strong statements to the effect that a lessor would not have intended to permit a lease to continue for a lessee's speculative purposes and for no real benefit to the lessor. ${ }^{93}$ This interpretation of the purpose of a freehold oil and gas lease as a whole led the Court to reject the argument of OMERS that any amount of production should suffice. ${ }^{94}$ The Court also dismissed the argument of the intervener Freehold Owners Association that a "paying quantities" standard should be implied, as that term was not expressly used in the Lease..$^{95}$ 
The confusion surrounding the Court's adoption of the "meaningful quantities" standard stems from the fact that the Court did not articulate a definite test that would enable the "meaningful quantities" standard to be distinguished from the "paying quantities" standard already generally understood by the industry to mean production revenues in excess of operating costs. ${ }^{96}$ The only guidance provided by the Court as to the application of the "meaningful quantities" standard was a very broad test: "Would a reasonably prudent operator, for the purpose of making a profit and not merely for speculation, continue to operate a well in the manner that it does? Or put simply, 'Is there a reasonable expectation of profitable returns from the well?'",97

Taken together with the Court's refusal to adopt the "paying quantities" standard argued for by the intervenor Freehold Owners Association, the above test would suggest that the Court intended a distinct standard from that of paying quantities that would be further refined by its application to other cases. ${ }^{98}$ The Court greatly confused the matter, however, by further providing that it did not see a significant difference between "meaningful" and "paying" quantities. ${ }^{99}$ It also stated that, in certain circumstances, the "paying quantities" standard might "provide more latitude" than the "meaningful quantities" standard. ${ }^{100}$ It is unclear what the Court meant by this statement, since it is seems implicit from the whole of the decision that the "meaningful quantities" standard is intended to be a more lenient standard than the "paying quantities" standard and easier for a lessee to satisfy. As a result, in our view, prudent lessees will have little choice but to assess whether wells are "capable of producing" by applying the paying quantities standard until such time as future cases clarify the "meaningful quantities" standard and how it is different from the paying quantities standard, if at all.

The Court of Appeal also endorsed the findings of the Texas Supreme Court in Clifton to find that whether a well was capable of producing in meaningful quantities was not to be determined on a moment-by-moment basis. ${ }^{101}$ However, it failed to confirm just how far Canadian courts would be willing to indulge a lessee that was willing to produce a marginal well. While the Court of Appeal's endorsement of Clifton might be interpreted as a rough guideline that a loss for a few months is acceptable as long as a well is generally profitable, there seems to be a question in that decision as to whether the Court really considered there to have been a true loss at all for the period. The Court also found that even if there was a loss, the well in question resumed production in paying quantities within the 60 -day cessation period contained in the lease. ${ }^{102}$ Thus, Clifton does not appear to provide a very good guideline. A better guideline might be found in the ERCB's interpretation that a well must have the "demonstrated, present ability .... to produce the leased substances in a meaningful quantity within the timeframes contemplated in the lease," which would suggest that a well must be demonstrably capable within the cessation period of the governing lease in order to be considered "capable of producing the leased substances." "103 This position is supported by

See Stevenson v Westgate, [1941] 2 DLR 471 (Ont SC), varied [1942] 1 DLR 369 (Ont CA).

OMERS, supra note 1 at para 96.

Ibid.

Ibid at para 95 .

Ibid.

Ibid at paras 69, 96 .

Ibid at para 3.

OMERS (ERCB), supra note 1 at 9 [emphasis added]. 
the Alberta Court of Appeal's statements that the interpretation of the Lease should not result in making the 90-day cessation clause meaningless. ${ }^{104}$

One question that both courts and lessees are likely to find difficult to answer in down markets like the present, is whether wells that do not generate a return in excess of operating costs but would be able to do so at higher prices can be considered "capable of producing." This is a particular concern with gas wells given that, at the time of writing, natural gas prices are at a ten-year low (in nominal terms). Given the Alberta Court of Appeal's articulation of the preliminary test for "meaningful quantities" as whether the lessee had "a reasonable expectation of profitable returns from the well," it is possible that a future court may consider it necessary to review the price forecasts of a lessee and the reasonableness of those forecasts in order to assess the validity of a lease held by such a marginal well. ${ }^{105}$ Where such forecasts do not support a reasonable expectation that a well will return to profitability within the applicable cessation period, leases held by such wells may be found to have terminated.

\section{StATE OF COMPLETION AND EQUIPPING OF A WELL}

The finding of the Court of Appeal in OMERS that a well must be able to produce in its existing state and configuration in order to be considered "capable" did not precisely determine the extent of a lessee's obligation in respect of the physical state of a well. In order to ensure that a well is "capable of producing the leased substances," is a lessee only required to complete a well such that it can be production tested at the wellhead? Or, is it further required to equip the well so that production can actually be taken and marketed by installing batteries, pipelines, and other necessary production infrastructure?

This issue gained prominence in the decision of the Alberta Court of Queen's Bench in Bearspaw Petroleum Ltd. v. Encana Corp., ${ }^{106}$ an action by Bearspaw Petroleum Ltd. (Bearspaw) for a declaration that a petroleum and natural gas lease was valid. The lease in question was granted by Encana's predecessor to Bearspaw's predecessor on 7 November 1960 for a primary term of ten years "and so long thereafter as the leased substances or any of them are producible from the leased area." 107 In order to continue the lease, Bearspaw relied on two wells drilled in October 1999 and December 2000. Both were completed at the wellhead and tested as viable gas producers. However, as a result of a lack of pipeline infrastructure in the immediate area, neither well was tied-in to enable actual production. ${ }^{108}$ Encana argued that the fact that the wells were not tied-in to a pipeline meant that they could not be considered "producible" for the purpose of continuing the lease. ${ }^{109}$

On its face, the decision presented an ideal opportunity for the Court to determine the extent of a lessee's obligations with respect to the physical state of a well; specifically, in the context of a gas well, whether a pipeline tie-in was required in order to continue a lease

OMERS, supra note 1 at para 92.

Ibid at para 96.

2010 ABQB 225, 34 Alta LR (5th) 165 [Bearspaw], aff'd 2011 ABCA 7, 39 Alta LR (5th) 302

[Bearspaw (CA)].

Bearspaw, ibid at para 4 [emphasis added].

Ibid at para 8.

Ibid at para 11 . 
incorporating some variation of a "capable" requirement. In the Court's view, however, that issue was not directly engaged as a result of the language used in the lease. It held that:

Producible does not mean that the product must be able to go to market without anything more to be done. A successful well remains producible in plain language even though the actual flow of gas to market awaits regulatory approval, well-head completion or contractual arrangements with carriers.

When, after a well is drilled, leased substances are found in economic quantities, those substances are capable of being produced when other things are done — that is, they are "producible." 110

Thus, the Court held that the term "producible" contemplated the lessee conducting future operations in order to actually achieve production, which could include the construction of a pipeline. It did not, as contended by Encana, require that a well be capable of "current and actual production to market."111

The findings of the trial judge were upheld on appeal, where the Court of Appeal commented further on Encana's position and stated that an interpretation requiring a pipeline tie-in in order to continue a lease would be "both commercially unfeasible and even absurd," as it would require a lessee "to build a pipeline at the same time as drilling in every case or risk having the lease terminated," 112 notwithstanding that the viability of the well might not have been determined at that time.

OMERS represented yet another excellent opportunity for the Alberta Court of Appeal to determine the extent of a lessee's obligations with respect to the physical state of a well. Unfortunately, it did not take advantage of that opportunity. The Court focused on the fact that the 5-4 well was not "capable of producing the leased substances" and saw no need to take its analysis further. It distinguished Bearspaw (CA) on the basis that the wells at issue in that case were acknowledged to be ready and able to produce at the tap, and the issue of whether the well was capable of producing gas and in what quantities (the primary issue in OMERS) was not engaged. ${ }^{113}$

There is, therefore, no Canadian court decision directly on point to conclusively determine the extent of a lessee's obligation regarding the physical state of a well that must be "capable" in order to continue a lease. However, the strong language used by the Court of Appeal in Bearspaw (CA) leads to the reasonable conclusion that it would not be necessary for a lessee to equip a well to the point that production could actually be taken to market for the purpose of continuing a petroleum and natural gas lease incorporating the phrase "capable of producing the leased substances," as interpreted in OMERS.

This interpretation appears to be consistent with obiter in a handful of prior Canadian decisions that commented on the capability of wells despite that such capability is not central to the decision. The most significant of such cases is probably Gunderson, discussed above, where it was stated by a unanimous Supreme Court of Canada that a well on pooled lands 
that was completed and capped, but not connected to a gathering system, was nonetheless "capable of producing natural gas.". 114

In 549767 Alberta Ltd. v. TEG Holdings Ltd., ${ }^{115}$ the Court of Queen's Bench of Alberta addressed the continuation of a lease upon which two wells had been drilled to completion and then shut-in before being connected to a gathering system. The issue in the case was whether the lessee had satisfied the requirements of the shut-in clause with respect to a lack of market or transportation facilities, and the Court held that it had not. In reaching this finding, the Court addressed the economic viability of the wells and appears to have treated the term "economic" as being roughly synonymous with the term "capable."116 It held that one of the wells at issue was in fact economic, despite the lack of a completed pipeline tie-in (which in the circumstances was fatal to the lease). ${ }^{117}$

Although Gunderson and TEG Holdings both dealt with the construction of a tie-in pipeline in the context of a gas well, their findings on this issue would seem equally applicable to the construction of a battery and related infrastructure in the context of an oil well. In Cull (SCC), discussed above, the Supreme Court of Canada specifically noted that the well was "capable of producing oil" as of the moment it was successively tested for oil production at the wellhead, ${ }^{118}$ which was before any treatment or storage equipment was installed by the lessee.

Given the recent trend in the industry of challenges to the well licences of lessees holding allegedly terminated leases (discussed in more detail below), it appears likely that this issue might come before the ERCB before it reaches the courts. The past position of the ERCB with respect to this issue is unclear as a result of contradictory decisions. In Nycan Energy Corp. and Diaz Resources Ltd., Compulsory Pooling, Enchant Field,${ }^{119}$ which assessed an application for compulsory pooling, the ERCB held that one of the wells drilled on the relevant lands was "capable of production" despite that it was not tied-in. ${ }^{120}$ The same position was taken by the ERCB in New North decision, ${ }^{121}$ where it was held that the well at issue was "capable of production" despite that it had not been tied into a gathering system. ${ }^{122}$ This is significant given that the New North decision was released subsequent to the ERCB decision in OMERS (ERCB).

Other ERCB decisions, however, have reached the opposite conclusion. Addressing a holding application in its Vintage decision, ${ }^{123}$ the ERCB made a distinction between wells that were and were not tied-in. It noted that there were 29 wells "capable of production" from

\footnotetext{
Gunderson, supra note 77 at 427.

[1997] AJ no 321 (QL) [TEG Holdings].

Ibid at paras $15-17$.

Ibid at para 17.

Cull (SCC), supra note 82 at 93.

(June 2000) EUB Examiner Report 2000-5, Application No 1052140, online: ERCB <http://www.ercb. ca/examiner-reports/2000/e2000-05.pdf>.

Ibid at 7-8.

ERCB, New North Resources Ltd, Section 39 Review of Common Carrier Order No Misc 2009-027, Knopcik Field (23 February 2010) ERCB Decision 2010-010 [New North].

Ibid at 3 .

123 EUB, Vintage Petroleum Canada, Inc Applications for Special Gas Well Spacing, Sturgeon Lake South
} Field (23 June 2003), EUB Decision 2003-049 [Vintage]. 
the pool being considered "and an additional 3 wells not yet tied in." ${ }^{124}$ It is clear from the decision that the ERCB did not consider the three wells that were not tied-in to be "capable of production," but the issue was not discussed any further. Even more significant is the decision of the ERCB in Desoto (ERCB), which assessed the validity of a well licence held by Desoto. In that decision, the ERCB applied the Supreme Court of Texas decision in Anadarko and held that a completed gas well that was shut-in as a result of lack of pipeline facilities did not constitute a well "capable of producing in paying quantities." " 25 In our view, however, the ERCB misinterpreted this decision. The finding of the Texas Court was that a well that is shut-in as a result of the lack of pipeline facilities "does not sustain a mineral interest that lasts as long as oil or gas "is produced""126 — in other words, a lease that requires actual production in order to continue. The Court in Anadarko had determined, however, that the lease in question would be sustained by both actual production or a well that was "capable of production" according to its terms. Where a well has been determined to be "capable of production" and is then shut-in, other US cases have found that the lack of a connection to a pipeline is not fatal to the lease. ${ }^{127}$

The strong statement in Bearspaw (CA) regarding the absurdity of constructing a tie-in pipeline at the same time as drilling a well may carry sufficient weight that a court addressing this issue in the future would hold that a lessee is not required to equip a well to the extent required to actually take production of leased substances in order for such well to be considered to be "capable," provided that the well otherwise satisfies the test expressed in $O M E R S$ and the requirements of the applicable lease. This raises an interesting question, however. Would it not defeat the intent of the lessor, as determined by the Alberta Court of Appeal, if the lessee was not, following the completion of drilling and testing, required to commence to construct pipeline connections, batteries, and other facilities, as applicable, so that production could be taken, transported, and marketed from the well? Perhaps within the relevant cessation clause in the lease? If not, a lessee could continue a lease with a well that could satisfy the "capable of producing the leased substances" requirement through testing, but could not actually produce. Such a well could, therefore, provide no real benefit to the lessor. This seems inconsistent with the Court's application of an "implied covenants" framework to the interpretation of the Lease and its strong statements regarding the need to interpret the Lease in a manner that benefits the lessor as well as the lessee. ${ }^{128}$

\section{THE PRUDENT OPERATOR STANDARD}

As noted above, the Court of Appeal indicated that the prudent operator standard would be part of the determination of whether a well was "capable" of producing the leased substances in "meaningful quantities." The Court stated: "As noted ... some questions a tribunal might ask are: Would a reasonably prudent operator, for the purpose of making a profit and not merely for speculation, continue to operate a well in the manner that it

\section{$124 \quad$ Ibid at 3}

125 Desoto (ERCB), supra note 42 at 10.

$126 \quad$ Anadarko, supra note 44 at 557.

127 See e.g. Levin v MAW Oil \& Gas, LLC, 234 P 3d 805 (Kan Sup Ct 2010).

128 OMERS (ERCB), supra note 1 at 8-9. See also the statement of the ERCB that "the lessee is not excused from making reasonable efforts to produce if ... relatively routine operations can increase recovery of the leased substances from the lands" (ibid at 8), which was not commented on by the Alberta Court of Appeal. 
does?" 129 In our view, the adoption of this standard raises additional uncertainties with respect to the interpretation of freehold leases.

The concept of a prudent operator has been adopted in US jurisdictions which have found implied covenants to produce and market leased substances. In Williams \& Meyers it was noted that, once it is determined that such implied covenants exist, the question arises as to the standard of care that governs the conduct of the lessee. ${ }^{130}$ One view is that the standard of care is governed by the prudent operator standard, which was described by the Court in Brewster as follows: "Whatever, in the circumstances, would be reasonably expected of operators of ordinary prudence, having regard to the interests of both lessor and lessee, is what is required." 131

The connection between implied covenants and the applicable standard of care was succinctly expressed by the Commission of Appeals in Rhoads Drilling Co. v. Allred:

\footnotetext{
The leases contain no express agreement on the part of the lessees to equip wells for the pump after they have ceased to flow... The duty to equip wells is but a part of the duty to develop and operate the property and market the production. A lessee's obligations in the performance of the implied covenants as to development, operation, equipping, and marketing are measured by the same rule, reasonable diligence, or what an ordinarily prudent and diligent operator would do. ${ }^{132}$
}

The Alberta Court of Appeal even suggested that, given that the rationale for implying a requirement for "paying quantities" in the leases cited by the American authorities was the same or similar to the rationale for implying a requirement of "meaningful quantities," the tests in US cases such as Clifton "may prove helpful guides." 133

Given the apparent willingness of the Alberta Court of Appeal to interpret freehold leases in a manner that has the same effect as the US recognition of implied covenants, it would appear that an issue likely to be raised in a future decision is whether this "prudent operator" standard should be read into Canadian freehold leases in a manner similar to the US courts in Brewster and Rhoads. In OMERS, the Court further highlighted the prudent operator issue when it commented that the suspended wells clause in the Lease does not describe when shut-in may occur and that none of the parties challenged the right of OMERS to shut-in the 5-4 well for any reason. Noting that the issue of entitlement was not engaged in the appeal, the Court nonetheless proceeded to raise, but not determine, the issue of whether a well "can only be shut-in for prudent reasons." 134 The Court stated that

$[\mathrm{u}]$ nlike some Canadian oil and gas leases, the Cymbaluk Lease does not (apart from the Force Majeure Clause) describe when shut-in may occur... [N]one of the parties to this appeal challenged the right to shutin a well for any reason whatsoever. As the issue of entitlement to shut-in is not directly engaged in this appeal, I leave to another day the question of whether the language of this lease, viewed objectively,

OMERS, supra note 1 at para 96.

Martin \& Kramer, supra note 55 at $\$ 806$.

Supra note 72 at 814 . See also Martin \& Kramer, ibid at $\S 802$.

70 SW 2d 576 (Tex Sup Ct 1934) at 584-85 [Rhoads].

OMERS, supra note 1 at para 96.

Ibid at para 46. 
demonstrates a common intention that a well, even one "capable of producing", can only be shut-in for prudent reasons. ${ }^{135}$

Accordingly, it seems logical, and entirely consistent with the US case authorities endorsed by the Court of Appeal, that, had this question been raised, the Court would have expressly applied the prudent operator standard in order to answer this question. To have held, notwithstanding the lack of express restrictions on the ability of the lessee to shut-in a well "capable of producing the leased substances," that a lessee could shut-in a well for any reason whatsoever would have undermined the "objective intention" of the parties to the Lease and defeated "the purpose of the parties in entering into" the Lease, which the Court held was "to discover and exploit available resources quickly and efficiently so that both parties can profit — the lessor through a royalty, and the lessee through the sale of the resource." 136

While there is some support in Canadian case law for using the "prudent operator standard" to extend the duration of a lease (in other words, as a shield), there does not appear to be any judicial support for using the "prudent operator standard" as a basis for shortening the duration of an estate in the absence of an express clause to the contrary (in other words, as a sword).

For example, in Cull (SCC), the Supreme Court of Canada upheld a lease that had neither production nor deemed production for a period of six days, during which the lessee installed the equipment necessary to treat and store production from the well. The Court upheld the lease on the basis that the lessee "had a bona fide intention to proceed diligently to place that well on production, which intention it carried out with reasonable diligence and dispatch."137 Cull (SCC) was endorsed in both Montreal Trust Co. v. Williston Wildcatters Co. ${ }^{138}$ and Canadian Superior Oil Ltd. v. Crozet Exploration Ltd. ${ }^{139}$ as recognizing that such short periods of inactivity or delay were within good oil field practice.

In Kensington, the Court of Appeal addressed (and rejected) the arguably similar concept of a shut-in for good oilfield practice. There being no express restriction on the ability of the lessee under the lease in question to shut-in the well and take advantage of the shut-in well provisions, the Alberta Court of Appeal disagreed with the finding of the trial judge that a shut-in must be carried out following good oilfield practice in order to constitute deemed production for the purpose of continuing the lease. ${ }^{140}$

Thus, while the strict interpretation of leases to which lessees have generally become accustomed may give rise to unfair results to one party or the other, it has an element of certainty that is lacking in the application of the "prudent operator" standard, which by its

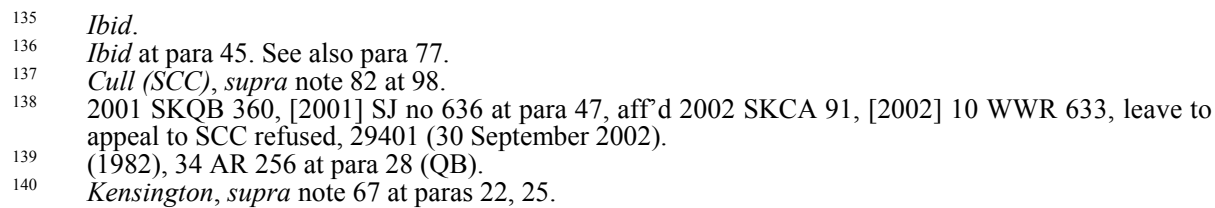


nature requires the consideration of a variety of factors. ${ }^{141}$ To the extent that the "prudent operator standard" operates as a "special limitation" on the estate, the approach generates much more uncertainty and complexity into the question of lease interpretation. Unless or until the question is decided by a court in any given instance, the lessor and lessee may be faced with further uncertainty as to the validity of their lease.

\section{FORCE MAJEURE}

Construing the Habendum together with the definition of "operations" in the Lease, the Court of Appeal concluded that "at the end of the primary term the lease will only be extended if the lessee is conducting operations, as defined, without a cessation of more than 90 days. " ${ }^{142}$ Recognizing the potential harshness of this interpretation on the lessee, the Court noted that the Lease provides relief from the stringency of the lease continuance provisions in certain circumstances, citing both the force majeure clause and the suspended wells clause as examples, along with the cessation clause. ${ }^{143}$ Although the existence of an event of force majeure and the operation of the force majeure provision in the Lease was not an issue in the decision, the Court's apparent faith in the flexibility provided to the lessee by the force majeure clause raises the question of whether the force majeure provisions are as beneficial to a lessee as the Court implies.

Canadian courts have clearly and consistently held a lessee's decision to produce from leased lands (or achieve deemed production) and thereby continue a lease is an option, not an obligation. ${ }^{144}$ Perhaps the strongest example of this finding comes from the case of Kanstrup, in which it was held, in respect of the force majeure clause, that:

\footnotetext{
That clause speaks of "obligations under this lease" which the appellant is prevented from performing for any of the reasons set out in the clause. The lease did not contain an obligation requiring the appellant to produce. It is true there is an automatic termination at the end of the primary term if there is no production. But although the lease may be lost if there is not production, there being no "obligation" to produce, [the force majeure clause] does not in my opinion assist the appellant. ${ }^{145}$
}

On further appeal to the Supreme Court of Canada, the Supreme Court endorsed the finding of the Court of Appeal and held that

while the clause postpones obligations, in certain events, it does not purport to modify the provisions of the habendum clause. That clause imposed no obligation upon the appellant to produce oil, gas or other mineral from the [said lands]. It only provided that the primary term could be extended if oil, gas or other mineral

See e.g. Spiller v Moore, 406 P 2d 467, (Okla Sup Ct 1965) at 472, where the Court found that a prudent operator might be required to consider: "(1) the quantity capable of being produced from the premises as indicated by prior exploration and development; (2) the local market or demand; (3) means of transporting to market; (4) extent and result of operations, if any, on adjacent lands; (5) character of the reservoir; (6) usages of the business."

$O M E R S$, supra note 1 at para 39.

Ibid at para 40 .

See e.g. East Crest Oil Co Ltd v Strohschein, [1952] 2 DLR 432 at 436 (Alta SC (AD)); Krysa v Opalinski (1960), 32 WWR 346 at para 7 (Alta SC); Canadian Superior Oil of California Ltd v Kanstrup (1964), 43 DLR (2d) 261 (Alta SC (AD)) [Kanstrup], aff'd [1965] SCR 92 [Kanstrup (SCC)]; Durish $v$ White Resource Management Ltd (1987), 82 AR 66 (QB).

Kanstrup, ibid at 278 [emphasis added]. 
was produced. If none of those substances were produced within the primary term, the lease terminated at the expiration of that term. ${ }^{146}$

There are two primary implications of this finding. One is that an oil and gas lease will terminate automatically upon the failure of the lessee to exercise its option to continue the lease by producing or achieving deemed production in the secondary term of the lease. Notably, and contrary to the understanding of lessees in some cases, the lessor is not required to serve the lessee with a notice of default before such termination will take effect. The second is that a lessee will not be subject to an action for damages by the lessor for the failure to produce from leased lands. For example, the lessee may simply choose to walk away from a lease and let it terminate if it considers the lands to no longer be productive and wishes to allocate its capital elsewhere.

It will be a surprise to many that this finding also has significant implications for the availability of relief from force majeure in many freehold oil and gas leases. The reason has to do with the distinction between the existence of an event of force majeure and the relief that the lease provides to the lessee in such circumstances.

Force majeure is commonly defined in freehold leases and other commercial agreements as the existence of an event beyond the reasonable control of a party. Usually a list of both specific inclusions and exclusions will also be inserted into the definition, with the lack of finances being, perhaps, the most common exclusion. In most agreements, the force majeure provision provides that a contracting party will be relieved from its obligations for the duration of an event of force majeure.

The use of the term "obligations" in a force majeure clause has a particular significance in the context of a freehold oil and gas lease that does not apply to most commercial agreements. It means that the relief granted by the force majeure clause will apply only to the lessee's obligations under the lease, the most significant of which are the lessee's obligations to pay rents and royalties and to comply with the offset well requirements. Relief will, therefore, not be granted to a lessee who fails to continue a lease by production or deemed production, since such matters are merely options and not obligations.

In the CAPL forms of petroleum and natural gas leases, however, an attempt appears to have been made to address the above issue. Unlike most non-CAPL leases, the force majeure clause is drafted as a two-part clause. The second part is a conventional force majeure clause and relieves the lessee only from its obligations under the lease upon the occurrence of an event of force majeure. ${ }^{147} \mathrm{It}$, therefore, suffers from the same problem discussed above. The first part, however, provides that the lease "shall not terminate" where "operations are interrupted or suspended or cannot be commenced as a result of force majeure"148 and for a 30-day period thereafter. The use of the term "obligations" directly incorporates the language used in the Habendum and the requirements the lessee must meet in order to continue the CAPL lease. Although no Canadian court has addressed this issue, it appears that the 
existence of an event of force majeure under a CAPL lease could operate to prevent termination of the lease even where the lessee failed to produce or achieve deemed production by the end of the primary term as a result of an event of force majeure.

Thus, while the Court of Appeal was correct to note that the force majeure provisions of the CAPL-form Lease could ameliorate the strictness of the Habendum, that may not be the case for other forms of leases. Where the force majeure clause purports to relieve a lessee only from its obligations under the lease upon the occurrence of an event of force majeure, it appears that the lessee must either recommence production within the applicable cessation period or seek to achieve deemed production under the shut-in or suspended wells clause in their lease in order to avoid termination of the lease when production has ceased. In circumstances where a lessee believes that an event of force majeure may exist, it would be well advised to have a lawyer carefully review the language used in its lease before attempting to rely on force majeure.

\section{IMPLICATIONS OF THE DECISION}

\section{A. Prior Termination OF Leases}

The most significant implication of the OMERS decision is the potential for prior termination of freehold oil and gas leases that contain the phrase "capable of producing" or some variation thereof in either the Habendum or the shut-in or suspended wells provision. Almost all forms of freehold leases terminate automatically once the lessee fails to satisfy the continuation requirements contained in the Habendum. The interpretation by the Court of Appeal that the phrase "capable of producing" requires a well to be able to produce a meaningful quantity of leased substances in its existing state and configuration, therefore, means that leases containing such language and continued by a well that has failed to meet that standard at some prior point in time will likely have terminated unless they can be saved by other provisions of the leases.

The prior termination of leases that have failed to meet the "capable of producing" standard may give rise to both damages claims by the lessor and the loss of the lessee's investment. Damages would likely be based on trespass or conversion for the period during which no valid lease existed and will be increased by the length of time that has passed since the effective date of termination. The quantum of those damages might be exponentially magnified where the lessee has gone on to drill additional productive wells on the leased lands, such as in areas that had historically low productivity but have now been opened up through the advent of horizontal drilling techniques. On the other hand, if a lease has previously terminated and the lessee has not produced or developed the lands subsequent to the date of termination, the identification that the lease has terminated may only give rise to abandonment and reclamation obligations.

A well will have failed to meet the Court of Appeal's interpretation of "capable of producing" in two broad circumstances: (1) when the physical state of the well was such that it could not produce; or (2) when the well could not produce a "meaningful quantity" of leased substances. 
Where the physical state of a well is inadequate to allow production as a result of an event beyond the control of the lessee (such as an equipment failure), the most likely type of relief that could be relied upon by a lessee would be a cessation clause granting the lessee a grace period during which operations could be conducted to bring the well back to a "capable" state in order to prevent termination of the lease. The cessation clause provides for relatively easy resolution of issues like equipment failure for lessees that are diligent in identifying and remedying such failures, but the failure to identify and promptly address such issues may prove fatal to the lease.

Depending on the circumstances, a lessee faced with an equipment failure or natural event may also be able to take advantage of a force majeure clause in the lease. As discussed above under the heading "Force Majeure," however, caution should be taken when doing so, as many force majeure clauses do not provide relief from the failure to satisfy the requirements of the Habendum or shut-in or suspended wells clause.

Where a lessee has intentionally taken steps to take the well out of a "capable" state for a period exceeding the length of any applicable cessation clause, relief may possibly be found in a clause requiring the lessee to conduct operations in compliance with all applicable legislation and the direction of governmental authorities, particularly where the reason that a well is not "capable" is as a result of a regulatory order. We have not identified any case where a well that is shut-in in compliance with legislation or a regulatory order resulted in the termination of a lease.

A more surprising circumstance that may give rise to the termination of a lease is where the lease is held by a well that was drilled, wellbore tested, and then immediately shut-in without being fully completed prior to the end of the primary term. Both the ERCB and the Court of Appeal expressly rejected the argument by OMERS that tests showing the presence of gas in the wellbore were sufficient to establish that the well was "capable." 149 Lessees currently engaged in drilling must, therefore, take care to ensure that a well is fully equipped and capable of being tested at the wellhead before shutting that well in. With respect to existing wells, however, the Court's finding could unfortunately mean the prior termination of leases that required a well to be "capable of producing" before being shut-in and that were purported to be continued on the basis of a shut-in well which was only wellbore tested.

A well will also not be "capable" according to the findings of the Court of Appeal in OMERS where it is unable to produce a "meaningful" amount of leased substances without an additional operation. As discussed above under the heading "The 'Meaningful Quantities' Standard," given that the quantity of production required to constitute "meaningful" was not clearly determined by the Court of Appeal, lessees would be well-advised to apply a "paying quantities" standard until such time as the "meaningful quantities" standard has been more clearly determined by the courts. It will perhaps not be difficult, however, for lessees to identify wells from which production does not come close to achieving either quantity standard. We have seen a number of such instances come to light in title reviews where freehold leases were purported to be held by wells for which production had either precipitously declined to a negligible amount or had been insignificant (in the nature of a 
couple of barrels a day) for an extended period of time. In such circumstances, it would likely be difficult for a lessee to justify continuation of the lease on the basis that such wells were producing a "meaningful quantity" of leased substances.

\section{B. TOP LEASING}

"Top leasing" refers to the practice of obtaining the right to obtain a future freehold oil and gas lease in respect of lands that are already subject to an existing lease. ${ }^{150}$ Although they have taken a number of different forms, the top lease in the form of an option to lease has been identified by Ballem as the most appropriate. ${ }^{151}$

Historically, top leases have been used by third parties seeking to challenge the validity of an existing lease that they suspect has previously terminated. Once the top lessee has protected its interest by way of caveat, the existing lessee will be prevented from taking any action that improves its position to the detriment of the interest of the top lessee. ${ }^{152}$ Interestingly, it is now not just third parties that may be interested in top leasing lands at risk of prior termination. Lessees that have proactively carried out an assessment of productive leases that have potentially terminated as a result of the OMERS decision would be well advised to top lease their own lands in certain circumstances in order to pre-empt any top leasing attempt by an interested third party. We have already seen instances of this occurring. Approaching a lessor to seek a top lease is likely to be a difficult subject, and it is not unheard of in the industry to "let sleeping dogs lie" when a prior issue with the validity of an existing lease is identified. However, if the value of the lands at risk is high and the governing lease is at a high risk of termination, failing to take some action to protect an investment creates a real and substantial risk of losing that investment to a top lessee that has come to the same conclusion, possibly with some assistance from the lessor.

As a result, we expect that such top leases will command a substantial premium in price (both in respect of bonus payments and increased royalties) over existing leases and top leases obtained by third parties, particularly where the lessor is a sophisticated corporate entity and well aware of the implications that the termination of the existing lease will have for itself and the lessee.

Given that the findings in OMERS potentially give rise to the prior termination of leases incorporating "capable of producing" or similar language in either the Habendum or the shutin or suspended wells provision, we expect to see a renewed interest in top leasing in the near future. Regardless of whether a top lease is sought by a third party or an existing lessee trying to protect its investment, it is clear that lessors, particularly those that are themselves able to identify existing leases that have potentially terminated as a result of OMERS, are in a commanding position with respect to such top leases and likely to reap a windfall.

Ballem, supra note 41 at 327.

Ibid at 328.

See Pan American Petroleum Corp v Potapchuk (1964), 46 WWR 237 (Alta SC) at 243, aff'd (1964), 51 WWR 700 (Alta SC (AD)), aff'd (1965), 51 WWR 767 (SCC), where the existing lessee was prevented from amending the pooling clause in the existing lease in a manner that would have resulted in it being valid once the caveat protecting the top lease was registered. 


\section{Challenging Lease Validity}

The potential termination of CAPL forms of freehold leases and any other form of lease incorporating "capable of producing" or similar language, as a result of OMERS, will give rise to a desire by both lessors and top lessees to take steps to challenge the validity of such leases.

The traditional method of challenging a lease is to challenge the validity of either the lease or the caveat protecting the lease. In order to challenge the lease, a claimant must seek a declaration from the courts that the caveat is no longer valid because the lease has terminated. If damages for trespass or conversion are being sought, the claimant might instead elect to file a statement of claim against the lessee, seeking both a declaration that the lease has terminated and damages for production following the effective date of termination.

A challenge to the caveat protecting the lease is brought by serving the existing lessee with a Notice to Take Proceedings on the caveat protecting the lease pursuant to section 138 of the Land Titles Act. ${ }^{153}$ Such notice must be made in the prescribed form and be properly served on the existing lessee at the address specified in the caveat. Unless the caveator initiates proceedings to substantiate the validity of the interest claimed by the caveat within 60 days of receipt of such notice, the caveat may be lapsed by application to the Registrar made after the expiration of such period.

A method of challenging a lease of more recent significance is by way of a challenge to the well licence held by the lessee. This type of challenge is brought to the ERCB by a claimant alleging that the current lessee no longer has the right to hold a well licence under section 16 of the Oil and Gas Conservation Act, ${ }^{154}$ which provides that no person shall "apply for or hold a license for a well ... unless that person is a working interest participant and is entitled to the right to produce the oil, gas or crude bitumen from the well or to the right to drill or operate the well for the other authorized purpose, as the case may be." In fact, the Freehold Owners Association now recommends that challenges be made to well licences by letter to the Compliance and Enforcement Department of the ERCB requesting the cancellation of the lessee's well licence. ${ }^{155}$ If the ERCB feels that there is merit to the request, it can notify the licence holder to establish its entitlement to continue to hold a well licence at a hearing held within 30 days pursuant to section 16(2) of the Oil and Gas Conservation Act.

The assessment by the ERCB during such a hearing of whether a party has the right to hold a well licence necessarily involves a determination by the ERCB of whether such party's lease is valid. In refusing leave to appeal the Desoto (ERCB) decision on the issue of jurisdiction, the Alberta Court of Appeal bluntly stated that "[ $\mathrm{t}]$ here is no merit to the argument that the [ERCB] does not have jurisdiction to deal with the validity of the lease, at least to the extent and only to the extent of establishing entitlement to apply for the well 
licence." ${ }^{\prime 156}$ In OMERS, the Court of Appeal did not even find it necessary to comment on the jurisdiction of the ERCB to assess lease validity in the context of a licencing hearing. As a result of the foregoing decisions, the jurisdiction of the ERCB to assess the validity of a freehold lease in the context of a licencing hearing must now be taken to have been clearly established. However, we understand that it is currently the position of the ERCB that it does not wish to be the preferred forum for parties to challenge the validity of a lease and that such claims should properly be settled between them or brought before the courts.

There are many factors to be considered by a party seeking to challenge an existing lessee's right to produce. Recent cases suggest that a challenge to a well licence at the ERCB is likely to proceed faster than a court action (assuming that the ERCB will entertain the challenge). This may be attractive to lessors that simply want an existing lessee off of their lands, particularly where the lessor is an oil and gas company that intends to drill on the leased lands itself. Revocation of the well licence will not likely be sufficient, however, for a lessor that intends to re-lease the lands, since the subsequent lessee or top lessee will probably be reluctant to develop the lands unless the caveat protecting the existing lease is first removed. In such cases, it may be necessary to either initiate a claim for a declaration that the existing lease has terminated or serve the existing lessee with a Notice to Take Proceedings in respect of the caveat.

A court action will also have to be initiated by a lessor that intends to seek damages for production following the termination of the lease. Thus, in order to avoid having to follow up a challenge to a well licence at the ERCB with a court action seeking damages, it may be preferable for a lessor in this position to forgo the ERCB route and proceed straight to a court application. Although this could be accomplished in separate actions - a declaration followed by a claim for damages - there is a risk that a court might look unfavourably on a plaintiff who unnecessarily separated related claims into two separate actions. If such a two-pronged approach of challenging the well licence at the ERCB and claiming for damages at the courts is nonetheless utilized, consideration should be given to the potential prejudice that an adverse finding by the ERCB (in other words, that the lease was in fact valid) might have on a related court action.

It would appear that top lessees that are primarily concerned with removal of the caveat protecting the existing lease and not in a position to claim damages are likely to continue to utilize the Notice to Take Proceedings in respect of the caveat.

\section{REDRAFTING OF LEASES}

The findings of the Court of Appeal in OMERS may give rise to the revision of lease forms in order to remove any "capable of producing" requirement and any uncertainty now associated with such phrase. In particular, we note that the CAPL has already circulated a 
revised draft lease form for industry comment. ${ }^{157}$ The proposed CAPL 2012 form we reviewed eliminates the "capable of producing" requirement entirely. In addressing the problem identified by the Court of Appeal of lessees being able to maintain shut-in wells indefinitely by making only a nominal payment to the lessor, the draft CAPL 2012 form (at the time of writing) provided that the lease will terminate unless cumulative production of 720 hours has not been achieved in each of the preceding three years in the secondary term. Other proposed changes are outside the scope of this article.

\section{E. INDUSTRY RESPONSE AND BEST PRACTICES}

During the course of writing this article, we carried out a series of meetings with corporate lessors and lessees in the upstream oil and gas industry. The intent of such meetings was to gauge the state of the industry's awareness of the implications of the OMERS decision and the steps being taken by both lessors and lessees to identify and deal appropriately with potentially at-risk leases.

The results of these meetings permit us to draw the following conclusions. First, knowledge of the significance of the OMERS decision is fairly good, at least at a senior level. Depending on the organization, however, that knowledge may or may not have been formally disseminated down to lower level staff. Second, industry participants are generally aware of some of the key implications of the OMERS decision for their operations, but not necessarily all implications or the severity of certain implications. For example, lessees may be aware that OMERS interpreted the phrase "capable of producing the leased substances" in an onerous manner, but not that the finding would be applicable to non-CAPL form leases incorporating the same terminology or that the finding in OMERS may impact their testing and completion practices. There is also confusion on the part of industry participants with respect to certain aspects of the decision and what actions should be taken in response to it, particularly with respect to the interpretation of the "meaningful quantities" standard. Finally, and most significantly from our perspective, lessees have generally not taken steps to identify leases at risk of prior termination. Such evaluations are typically conducted on a go-forward basis when rental or shut-in payments are made or before any new drilling is commenced, but most parties have not undertaken a company-wide assessment of leases containing the all-important "capable of producing" language.

As a result of the foregoing, it has become clear to us that the industry is in need of advice regarding how it should respond to the uncertainty created by the OMERS decision. Set out below is our suggested list of best practices to be followed:

(1) Conduct an assessment of all freehold leases with the purpose of identifying all leases that contain the phrase "capable of producing the leased substances" or a variant thereof in either the Habendum or the shut-in wells clause. 
(2) Identify potentially at-risk leases by reviewing the production history for any wells that contain "capable of producing the leased substances" language for gaps in production or periods of very low production that exceed the length of the applicable cessation clause in the lease.

(3) Carefully review lease terms, production records, and well files relating to potentially at-risk leases to determine whether such leases could be substantiated under the OMERS test during periods of cessations in production or low production given historical oil and gas prices. Particular attention should be paid to wells that were merely drill stem tested before being shut-in and leases with drastic decreases in production or extended periods of low production.

(4) Categorize at-risk leases according to both the risk of termination and the potential value of investment lost if the lease was challenged and could not be substantiated.

(5) Determine what steps will be taken with respect to each category of at-risk leases based on value and risk of termination. For high value leases at a high risk of prior termination, consider top leasing or otherwise validating before a third party obtains a top lease on the same lands. For low value leases at a high risk of termination, consider surrendering the leases and abandoning the wells, or perhaps packaging and selling to a party that is willing to take the risk or interested in validating the leases.

(6) Revise well testing and completion practices on a go-forward basis to ensure that all wells governed by affected leases are in a "capable" state before being shut-in, both in terms of the physical state of the well and its ability to produce a paying quantity of leased substances (until such time as the "meaningful quantities" standard has been more fully developed), taking current market conditions into account. If necessary, conduct an operation that results in the well being demonstrably capable to remove any doubt.

\section{CONCLUSION}

It is our position that the decision of the Alberta Court of Appeal in OMERS, while attempting to address a perceived unfairness towards freehold lessors, inadvertently resulted in the creation of additional uncertainties that will have a significant impact on both lessors and lessees. By adopting elements of US case law rather than searching for a "made in Canada" solution, the Court has changed the way that future courts will interpret freehold lease terms and has opened the door to the recognition of implied terms similar to those found in the US under the guise of interpreting the intention of the parties to the lease. By adopting new standards and raising matters not directly at issue in the case, without adequately determining or defining either, the Court has invited a period of patchwork approach to the interpretation of freehold leases by lower courts that will make it difficult for parties to understand their lease terms in the near term. 


\section{HABENDUM ${ }^{158}$}

\section{APPENDiX A}

TO HAVE AND ENJOY the same for the term of FIVE (5) years (herein called the "primary term") commencing on the date hereof and continuing so long thereafter as operations (as hereinafter defined) are conducted upon the said lands, the pooled lands or the unitized lands, with no cessation, in the case of each cessation of operations, of more than 90 consecutive days.

\section{INTERPRETATION}

b. "commercial production" means the output from a well of such quantity of the leased substances or any of them as, considering the cost of drilling and production operations and price and quality of the leased substances, after a production test of suitable duration and nature in accordance with good oil field practice, would commercially and economically warrant the drilling of a like well in the vicinity thereof;

c. "force majeure" means any cause beyond the Lessee's reasonable control and, without limitation, includes an act of God, strike, lockout, or other industrial disturbance, act of any public enemy, war, blockade, riot, lightning, fire, storm, flood, explosion, unusually severe weather conditions, government restraints, including road bans, but shall not include lack of finances;

g. "operations" means any of the following:

i. drilling, testing, completing, reworking, recompleting, deepening, plugging back or repairing a well or equipment on or in the said lands or injecting substances by means of a well, in search for or in an endeavour to obtain, maintain or increase production of any leased substance from the said lands, the pooled lands or the unitized lands;

ii. the production of any leased substance;

iii. the recovery of any injected substance; or

iv. any acts for or incidental to any of the foregoing; 


\section{SUSPENDED WELLS}

If, at the expiration of the primary term or at any time or times thereafter, there is any well on the said lands, the pooled lands, or the unitized lands, capable of producing the leased substances or any of them, and all such wells are shut-in or suspended, this Lease shall, nevertheless, continue in force as though operations were being conducted on the said lands, for so long as all the said wells are shut-in or suspended and so long thereafter as operations are conducted upon the said lands, the pooled lands or the unitized lands, with no cessation, in the case of each cessation of operations, of more than 90 consecutive days. If no royalties are otherwise payable hereunder during a lease year after the primary term within which such shut-in period or periods occur and during such lease year no other operations are conducted on the said lands, the pooled lands, or the unitized lands then the Lessee shall pay to the Lessor an amount equal to DOLLARS (\$ ) within 90 days after the expiry of such lease year (herein called the "suspended well payment").

\section{OFFSET WELLS}

If commercial production is obtained after the date of this Lease from an offset well, then unless (i) a well has been or is being drilled on the spacing unit of the said lands laterally adjoining the spacing unit of the offset well and into the zone or formation from which commercial production is being obtained from the offset well, or (ii) all or part of the spacing unit of the said lands laterally adjoining the spacing unit of the offset well has been pooled or included in a unit in which the pooled or unitized substances include production from the same zone or formation from which production is being obtained from the offset well, the Lessee shall within 6 months from the later of the date of the offset well being placed on commercial production or, if information with respect to the amount of production from the offset well is restricted pursuant to any statute, regulation, order or directive of any government or governmental agency and such information is unknown to the Lessee, until one month after such information is made public:

a. commence or cause to be commenced operations for the drilling of a well on the spacing unit of that portion of the said lands which comprises or is included in the spacing unit laterally adjoining the spacing unit of the offset well and thereafter drill, or cause to be drilled the same to the zone or formation from which production is being obtained from the offset well;

b. pool or unitize that portion of the said lands which comprises or is included in the spacing unit laterally adjoining the spacing unit of the offset well, such pooling or unitization to include production from the same zone or formation from which the offset well is being produced;

c. surrender all or any portion of the said lands pursuant to the provisions hereof, provided that the surrender shall include but may be limited to the zone or formation from which production is being obtained from the offset well underlying 
that portion of the said lands which comprises or is included in the spacing unit laterally adjoining the spacing unit of the offset well; or

d. pay to the Lessor at such times as royalty would be payable pursuant to the provisions of this Lease, until the provisions of paragraphs a., b. or c. of this clause are met, a royalty which shall be proportionately equivalent on an acreage basis to such royalty as would have been payable to the Lessor if the leased substances produced from the offset well were actually being produced from a well on the said lands which commenced production on the last day of the said 6-month period; provided, however, that should any spacing unit of the said lands laterally adjoin more than one spacing unit upon which is located an offset well from which commercial production is being obtained, the royalty which the Lessee may elect to pay to the Lessor pursuant to this subclause shall be calculated on the average of the production from the said offset wells, such average to be calculated by dividing the total production from all of the said offset wells by the number of all of the said offset wells.

Notwithstanding anything herein contained, the obligations imposed by this clause shall be deemed not to have arisen if:

a. the offset well shall cease to be capable of or ceases commercial production during the said 6-month period; or

b. the offset well is productive primarily or only of natural gas and the Lessee has not previously arranged an adequate and commercial market for the natural gas which might be produced from any well to be drilled pursuant to this clause.

\section{DEFAULT}

a. If, before or after the expiry of the primary term, the Lessor considers that the Lessee has not complied with any provision or obligation of this Lease, including but not limited to a failure to give notice or to pay in the manner specified any rental, suspended well payments, royalty or other sums for which specific provision is made in this Lease, the Lessor shall notify the Lessee in writing, describing in reasonable detail the alleged breach or breaches. The Lessee shall have 30 days after receipt of such notice to:

i. remedy or commence to remedy the breach or breaches alleged by the Lessor, and thereafter diligently continue to remedy the same; or

ii. commence and diligently pursue proceedings for a judicial determination as to whether the alleged acts or omissions constitute a breach or breaches on the part of the Lessee.

b. The performance of any act by the Lessee intended to remedy all or any of the alleged breaches shall not be deemed an admission by the Lessee that it has failed to perform 
its obligations hereunder. If the Lessee fails to remedy or commence to remedy a breach or breaches within the 30 day period, or if having so commenced to remedy a breach or breaches thereafter fails to continue diligently to remedy the same, and if proceedings have not been commenced for a judicial determination as aforesaid, this Lease, except for the Lessee's right with respect to the removal of equipment and its obligation to remove any registered document in relation to this Lease, shall thereupon terminate and it shall be lawful for the Lessor to re-enter the said lands and to repossess them. If proceedings for a judicial determination are commenced within the aforesaid period of time, this Lease shall not terminate until the existence of such breach has been finally judicially determined; nor shall it terminate if the Lessee within 30 days of such final determination has remedied or commenced to remedy the breach or breaches, and having so commenced to remedy the breach or breaches, thereafter diligently continues to remedy the same.

c. Notwithstanding anything contained in this Lease, this Lease shall not terminate nor be subject to forfeiture or cancellation if there is located on the said lands or on the pooled lands or on the unitized lands a well capable of producing leased substances or any of them, or on which operations are being conducted; and, in that event, the Lessor's remedy for any default under this Lease shall be for damages only.

\section{FORCE MAJEURE}

a. If operations are interrupted or suspended or cannot be commenced as a result of force majeure, this Lease shall not terminate during any such period of interruption, suspension or inability to commence caused thereby or for 30 days thereafter.

b. If the Lessee is unable, in whole or in part, by force majeure to carry out its obligations hereunder, other than any obligation to make payment of any monies due hereunder, then the obligations of the Lessee, so far as they are affected by such force majeure, shall be suspended during the continuance of any inability so caused; and the cause of the force majeure so far as possible shall be remedied with all reasonable dispatch.

c. Nothing herein shall require the settlement of strikes, lockouts or other labour disturbances except in the sole discretion of the Lessee. 